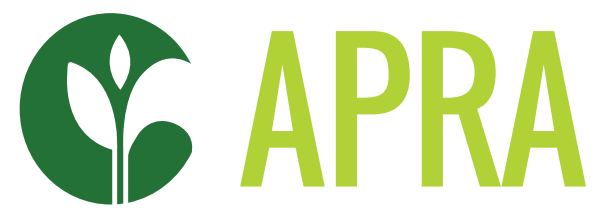

Agricultural Policy Research in Africa

\title{
YIELD AND COMMERCIALISATION EFFECTS OF SRI INTERVENTIONS IN MNGETA, KILOMBERO DISTRICT, TANZANIA
}

Devotha B. Mosha, Gilead Mlay, Colin Poulton and Amrita Saha 


\section{CONTENTS}

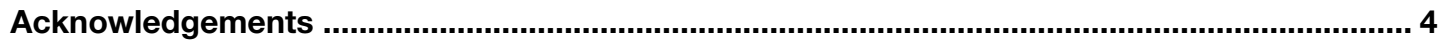

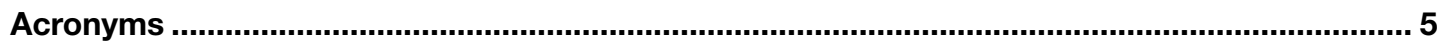

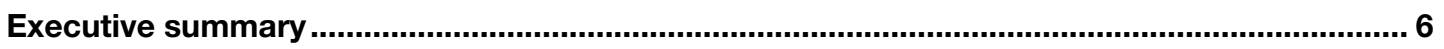

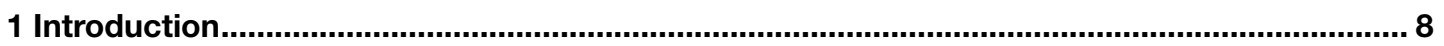

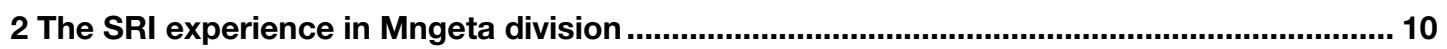

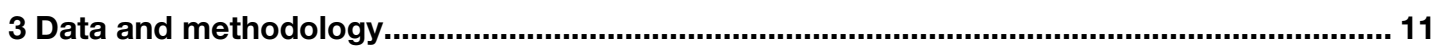

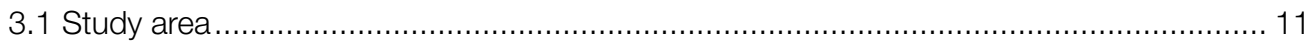

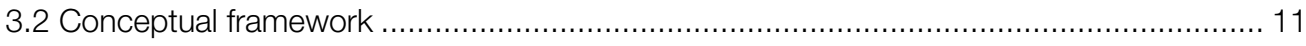

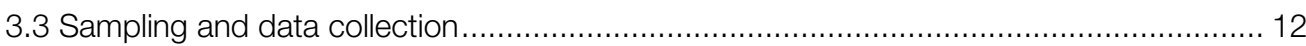

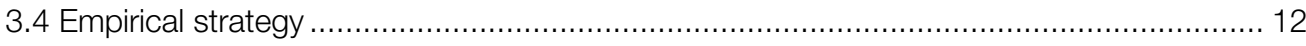

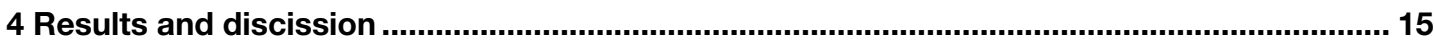

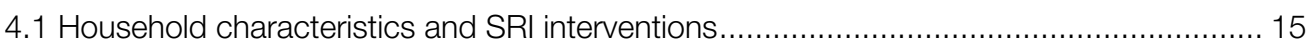

4.2 Training and the adoption of SRI management practices ....................................... 17

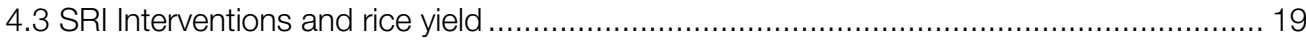

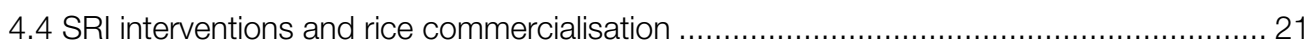

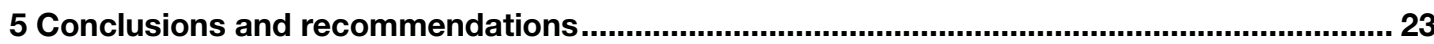

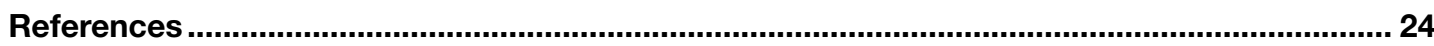

Annex 1: SRI adoption rate in percentage by SRI training and farmer group membership

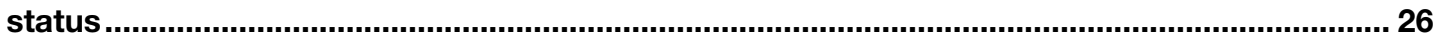

Annex 2: Description of production inputs and plot level variables for the production

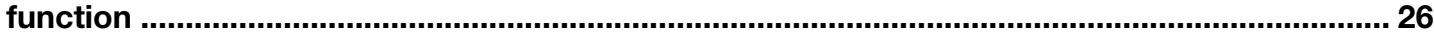

Annex 3: Terciles of rice commercialisation ................................................................... 27

List of tables

Table 4.1: Household and farm characteristics by SRI training status.............................. 15

Table 4.2: Households adopted SRI by training, membership and credit access ................... 16

Table 4.3: Distribution of paddy plots by plot type and SRI training status ......................... 17

Table 4.4: Characteristics of rice plots by declared SRI status......................................... 17

Table 4.5: Distribution of declared SRI plots by number of SRI practices.............................. 18

Table 4.6: Distribution of SRI plots for selected SRI practices combinations by training and

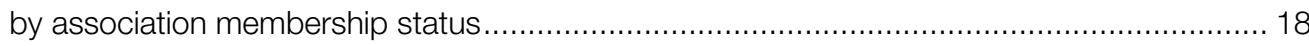

Table 4.7: Plot level paddy yield in t/ha by SRI management practices.............................. 19

Table 4.8: Mean difference paddy yield per plot level by training status ............................... 20

Table 4.9: Effect of SRI interventions on paddy yield: production function analysis ................ 20 
Table 4.10. Determinants of rice commercialisation......................................... 21

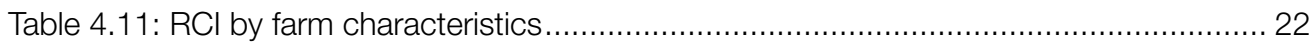

\section{List of figures}

Figure 3.1: Conceptual framework on SRI technology adoption and implication on paddy yield. 


\section{ACKNOWLEDGEMENTS}

The authors appreciate the financial support provided by the UK's Foreign, Commonwealth \& Development Office (FCDO). We thank all respondents in Mngeta division, Kilombero district who unconditionally provided their time to inform us about the effect of System of Rice Intensification (SRI) on productivity, paddy yield and commercialisation. Special thanks to Kilombero district authority, the Morogoro regional government authority and Tanzania Ministry of Agriculture staff members for their cooperation during data collection and triangulation of preliminary findings. The researchers hope that the experience gained on the contribution of SRI interventions on productivity and rice commercialisation, paddy yield and livelihood outcomes identified will be used to address and formulate sustainable solutions. The research team acknowledges the feedback and contributions received from members of the Agricultural Policy Research in Africa (APRA) for reviewing earlier drafts of this paper, as well as the coordinating secretariat at the Institute of Development Studies (IDS), University of Sussex.

Devotha B. Mosha is a Senior Research Fellow at the Institute of Continuing Education (ICE), Sokoine University of Agriculture (SUA), Tanzania. Gilead Mlay is a Professor at the School of Agricultural Economics and Business Studies (SAEBS), SUA. Poulton Collin is a Professor at the School of Oriental and African Studies (SOAS), University of London, UK. Amrita Saha is a Research Fellow at the Institute of Development Studies (IDS), University of Sussex, UK.

This working paper is funded with UK aid from the UK government (Foreign, Commonwealth \& Development Office - FCDO, formerly DFID). The opinions are the authors and do not necessarily reflect the views or policies of IDS or the UK government. 


\section{ACRONYMS}

APRA

Agricultural Policy Research in Africa

FGD

focus group discussion

FHH

female-headed household

HH

household

IDS

Institute of Development Studies

KII

key informant interview

KPL

Kilombero Plantation Limited

MHH

male-headed household

MSRI

Modified SRI

$\mathrm{RCI}$

Rice Commercialisation Index

SAGCOT

Southern Agricultural Growth Corridor of Tanzania

SRI

System of Rice Intensification

SSA

Sub-Saharan Africa

TLU

Tropical Livestock Unit 


\section{EXECUTIVE SUMMARY}

This paper discusses System of Rice Intensification (SRI) interventions and its potential effects on paddy yield and commercialisation in Mngeta division, Kilombero district in Morogoro region, Tanzania. $\mathrm{SRI}$ is an innovative agroecological methodology that aims to improve yields and farmer's profits by creating the most suitable environment for the rice plant to grow. It comprises the precise set of cultivation practices specifically required for careful management of biophysical needs of the rice plant for producing high yields. In Kilombero district, SRI was established in 2009 by Kilombero Plantation Limited (KPL) in collaboration with the government of Tanzania. Although several practices were promoted as part of the SRI programme, adoption and embracing of SRI technologies was not purely holistic in Kilombero. In addition, some of the so-called SRI practices feature in conventional agronomic recommendations (e.g. early and regular weeding) and may not even be accepted as SRI in some other contexts (e.g. use of inorganic fertilisers and herbicides). To assess the effects, we compare between trained and non-trained farmers as well as between farmers who are members of SRI associations and non-SRI members on aspects of adoption of SRI interventions, paddy productivity and yields. In turn, the effects of SRI is evaluated in terms of its influence on rice yield per hectare and commercialisation at household level.

The analysis draws from the first round data set of the Agricultural Policy Research in Africa (APRA) $)^{1}$ rice commercialisation study covering 537 rice-producing households selected randomly from ten villages in Mngeta division. The sample comprised of 463 smallscale farmers (86.2 per cent) and 74 medium-scale farmers (13.8 per cent). The sample had 471 (87.7 per cent) male-headed households (MHHs) and 66 (12.3 per cent) female-headed households (FHHs).

The study adopted a mixed methods approach where both qualitative and quantitative data were collected during the same period. Qualitative data were collected through focus group discussions (FGDs), key informant interviews (KIIs) and direct observation, whereas the quantitative data were based on the household survey. Data were processed using a combination of descriptive and econometric methods. The analysis followed three approaches: assessment of the level of association between the SRI interventions and household, as well as with plot attributes; a production function model to determine whether implementation of SRI management practices influenced paddy yields; and a fractional logistic model to assess the relationship between SRI interventions and rice commercialisation, controlling for the factors.

We found a significant association between SRI training and adoption of SRI management practices $(p<0.01)$. About 62 per cent of the farmers who received SRI training adopted SRI while only 36 per cent of nontrained farmers adopted SRI. The mean SRI adoption rate of about 57 per cent by trained adopters was significantly higher than that of 35 per cent by nontrained adopters $(p<0.01)$. The actual SRI practices adopted at plot levels varied widely among SRI adopters and non-adopters. There was a significant difference in the mean yield of paddy among plots with and without SRI practices. While plots without SRI practices achieved a mean yield of $2.4 \mathrm{t} / \mathrm{ha}$, plots with a combination of early and regular weeding achieved a mean yield of 3.3t/ha, and plots practicing a combination of raising seeding in a nursery, early and regular weeding and fertiliser application achieved a mean yield of $4.2 \mathrm{t} / \mathrm{ha}$. To achieve early and regular weeding it was essential to use herbicides.

Overall, herbicides were used on more than half (58 per cent) of all paddy plots, and a higher proportion (61.5 per cent) of the SRI plots used herbicides compared to only 49.3 per cent of the non-SRI plots. The production function analysis indicated age of household head, SRI training and most of the SRI practices (except seed) had a significant effect on the rice yield, holding other factors constant. The findings from the fractional logistic model revealed that a higher proportion of SRI-trained farmers and SRI group members attained

1 This is a consortium of several institutions that seek to assess whether agricultural commercialisationis happening in six African countries (Ethiopia, Ghana, Malawi, Nigeria, Tanzania and Zimbabwe), and if such commercialisation is inclusive. 
higher rice commercialisation. The estimated mean Rice Commercialisation Index (RCl) for SRI-trained farmers was about 9 per cent higher than that of nontrained farmers $(p<0.01)$; and there is a significant positive effect of productivity on rice commercialisation $(p<0.01)$.

Generally, the findings from this study lead to four important conclusions:

- $\quad$ First, several practices were promoted by KPL as part of the SRI programme, but adoption is not purely holistic. Farmers decide to choose at least one of the following SRI practices: raising seed in nursery; planting in row; early weeding and regular weeding. We note that plots with SRI practices had a mean yield gain of about 33 per cent above plots without SRI practices. Besides, plots with a combination of two or more SRI practices produce more paddy yield.

- $\quad$ Second, there is spill-over of the SRI training to other farmers who did not attend. This is a positive message for sustainability of SRI practices and that, in due course, it is likely that more farmers will adopt and benefit from rice commercialisation.

- Third, in order to attain significant yield and commercialisation levels, farmers need to adopt and apply holistic SRI package.

- $\quad$ Lastly, embracing SRI practices has a potential to increase paddy yields and $\mathrm{RCl}$ and subsequently increase income of farming household. Low application of SRI practices is attributed to the perceived high cost of inputs such as improved seed and for being labour intensive. 


\section{INTRODUCTION}

Rice is an important food and cash crop throughout Africa, Asia and other parts of the world. In Tanzania, rice is the second most important cereal crop (after maize) with an estimated average annual production of 2.2 million t, of which half is marketed (URT, 2009) - influencing the livelihoods of over 2 million people (Kahimba, Kombe and Mahoo, 2014). It is mainly produced under rain-fed conditions, with irrigation accounting for only about 20 per cent of the total cultivated area. Smallholder farmers cultivating between 0.5 ha and 3ha account for about 90 per cent of rice production in the country (URT, 2019). The crop and the sub-sector in general are considered strategic by the government, given the great potential for improving food security, income, export earnings and creating employment opportunities.

The strategic nature of the crop owes to both demand and supply factors. On the demand side, due to a high population growth rate in Sub-Saharan Africa (SSA) and Tanzania, estimated at about 3 per cent and 2.7 per cent, respectively, rapid urbanisation and growing incomes provide increased market opportunities for the crop. The demand for rice in Tanzania reached 2.27 million $\mathrm{t}$ in 2019 and it is projected to increase by 2.9 per cent per year during the next five years (URT, 2018). On the supply side, the large untapped water resources potential and suitable land for rice production, estimated at about 21 million ha, provide great opportunities to expand production. However, there are supply side constraints, and one such constraint is low productivity.

The most recent Five-year Development Plan II for 2017/2021 and the Agricultural Sector Development Programme II have included the rice value chain as an important food and commercial crop for inclusive development, and realisation of the Vision 2025 (URT, 2019). Furthermore, in 2010, Tanzania launched the Southern Agricultural Growth Corridor of Tanzania (SAGCOT) development framework that includes the promotion of the uptake of improved agricultural technologies, especially among smallholder farmers so as to enhance agricultural growth, improve food security, reduce poverty and ensure environmental sustainability through commercial agriculture. One technology promoted under the SAGCOT development framework was SRI.
SRI was first introduced in Kilombero district in 2009 by $\mathrm{KPL}$ - a large-scale producer of rice and maize within Mngeta division (Isinika et al. 2020). Smallholder farmers were expected to benefit from large-scale farmers within the vicinity of KPL through technological spill-overs, market linkages and employment. Globally, $\mathrm{SRI}$ is promoted as the best set of technologies with the potential to improve rice yields and transform rice production from subsistence to commercialisation (Uphoff, 2012; Katambara et al., 2013; Kahimba, Kombe and Mahoo, 2014; Gathorne-Hardy et al., 2016).

SRI technology evolved from the work of Father Henri de Laulanié, a French Jesuit priest, in Madagascar in the 1980s (Stoop, Uphoff and Kassam, 2002). It is an innovative agroecological methodology that aims to increase yields and farmer's profits by creating the most suitable environment for the rice plant to grow through careful management of the rice plant and efficient use of available water resources. According to Stoop, Uphoff and Kassam (2002) and Barrett et al. (2004), SRI includes the following elements; (i) raising seedlings in a carefully managed nursery, (ii) early transplanting of seedlings 8-15 days old, (iii) single widely spaced transplants, (iv) early and regular weeding, (v) carefully controlled water management (intermittent wetting and drying of fields) and (vi) application of compost to the extent possible. However, since its conception in the 1980s, SRI technology has been widely adapted to suit different conditions and farmers' circumstances (Glover, 2011; West, 2017). In Kilombero district, farmers have been observed to adopt SRI components selectively, depending on their situation, and ambiguity exists regarding the modification made on the use of fertiliser and herbicides, and with or without water management control mechanisms.

Experience from various countries such as Cambodia, Indonesia, the Philippines and Vietnam, which have adopted SRI technology, has demonstrated a significant yield improvement. For example Samant (2017) reported increased rice yield from 60 per cent to over 100 per cent in India. Uphoff (2012) also noted an average yield varying from 5.7-8.1t/ha under SRI practices. In Tanzania, SRI is gaining popularity among small, medium and large-scale farms and it has spread widely and rapidly in paddy growing areas within 
Kilimanjaro, Mbeya, Morogoro, Mwanza and Tabora regions (Katambara et al. 2013; Kahimba, Kombe and Mahoo, 2014). Studies carried out in different parts of Tanzania show that the SRI set of technologies have the ability to produce higher yields ranging from 3t/ha under conventional technologies up to 6-8t/ha under irrigation. The SRI technology also uses less water, saving up to 25 per cent of irrigation water (Katambara et al., 2013; Kahimba, Kombe and Mahoo, 2014; Nakano, Tanaka and Keijiro, 2017).

However, water management is not practiced by the majority of SRI farmers in Kilombero valley, and the application of inorganic fertilisers and herbicides that has been adopted is not a typical principle of SRI. Nakano, Tanaka and Keijiro (2017) have branded the SRI practices in Kilombero as a modified SRI (MSRI) to take into account the inclusion of inorganic fertiliser and its application under rain-fed conditions. MSRI has posed several challenges, including crop loss due to water logging, soil fertility losses due to leaching, and reduced supply of water for downstream water users as well as increases in cost of production, which is contrary to SRI's goals. As a result, the distinction between SRI and non-SRI farmers has been ambiguous in the Kilombero district and ambiguity exists regarding the extent to which the various elements of SRI are in fact combined and how this influences yields and commercialisation levels.

To test the SAGCOT hypothesis regarding technological spill-overs from large-scale farmers to small-scale farmers and subsequent improvement of rice commercialisation, this paper presents lessons learned and policy implications from the practice of MSRI interventions, and findings for yield and rice commercialisation among smallholder farmers in Kilombero district. The paper draws on data from the APRA consortium that examines the role of agricultural commercialisation in fostering inclusive livelihood improvement. 


\section{THE SRI EXPERIENCE IN MNGETA DIVISION}

In Kilombero, over 90 per cent of the rice farming is rain-fed; growing on lowland rice fields, implying that less than 10 per cent of the crop is irrigated. Under the traditional farming system, both irrigated and rain-fed rice fields are covered with water throughout the growing season. Such a system poses several challenges, including crop loss due to water logging, soil fertility loss due to leaching and reduced supply of water for downstream water users. While many development agents have promoted SRI technology in Kilombero, the story of SRI in Mngeta division is strongly linked to the KPL farm that is located within the division.

During the 2009/2010 cropping season, KPL, working in collaboration with the United States Agency for International Development and other development agencies, introduced SRI to improve productivity and production among smallholder farmers in order to improve their income and livelihoods (Wilson, 2016; West, 2017). Smallholders and medium-scale farmers were trained on the technical aspects of SRI as well other aspects including the power of collective action through groups for resource acquisition and marketing. By 2017, when the APRA study on rice commercialisation was conducted, a total of 8,043 farmers had undergone initial SRI training. After the training, farmers were organised into SRI groups, through which credit, technical as well as monitoring support were channeled. However, not all farmers who had attended training joined these farmer groups. Only 106 members of SRI associations were located in the ten villages that were selected for the study.

As discussed above, the MSRI adopted in KPL has been unique. It takes into account the inclusion of inorganic fertiliser and its application is under rain-fed conditions. Below we draw attention to some of the features that make SRI unique in KPL.

First, from the literature, SRI technologies are best suited for farms or plots within irrigation schemes, where water can be managed. However, in Mngeta division, only Njage village has a well-developed irrigation scheme, implying that most farmers using SRI are operating under rain-fed conditions. Nonetheless, some farmers have adapted the water management practices even on non-irrigated farms.
Second, to ensure that farmers had access to all the required inputs, Yosefu Microfinance and YETU bank facilitated acquisition of inputs. The use of purchased inputs is however not part of the original SRI vision introduced by Fr. Henri de Laulanié.

Third, in another departure from the original SRI vision, SRI group members in Mngeta division were encouraged to plant a higher yielding hybrid rice variety (SARO-5), which was also planted on the KPL estate so that farmers could sell their paddy to KPL (Isinika and Mwajombe, 2018). However, this lasted for only a few seasons due to significant competition from smallscale independent buyers, which prefer rice produced by local seed varieties because it has better aromatic attributes than SARO- 5.

Overall, given the present average yield in Mngeta division of 2t/ha, findings suggest a 50 per cent potential yield gain should be attainable when the SRI package is implemented correctly. However, Krishna, Biradarpatil and Channappagoudar. (2008) argue that the actual yield gain from the SRI interventions will vary based on the training package, seed variety, local conditions and how well the SRI practices are implemented.

Further, Nakano, Tanaka and Keijiro (2017) assessed the impact of rice production training in a modified version of SRI for technology adoption on rice yield and profitability under rain-fed conditions using plot level data from Kilombero in 2014. Our study builds on this stream of work, and uses cross sectional data for 2016/17 from the same geographical area to assess SRI interventions, rice yield at plot level and rice commercialisation at household level. 


\subsection{Study area}

The study area of Kilombero district is in central-southern Tanzania and the study population is composed of paddy farming households. A total of 537 rice-producing households were selected randomly from ten villages restricted to $30 \mathrm{~km}$ from $\mathrm{KPL}$, covering villages from Mchombe, Mngeta and Chita wards in Mngeta division. Out of 537 respondents, 463 were small-scale farmers (86.2 per cent) and 74 were medium-scale farmers (13.8 per cent). The sample comprised of 471 (87.7 per cent) MHHs and 66 (12.3 per cent) FHHs. Given that the focus of this paper is on SRI interventions, paddy productivity, yield and commercialisation of smallscale farmers, the small-scale farmers and SRI farmers were combined and then post-stratified in terms of SRI training status and membership to SRI farmers' groups. For the purpose of this study we classified farmers as small-scale if their land area under cultivation was below 5ha, as medium-scale if they are between 5.1-20ha, and large-scale above 20 ha.

\subsection{Conceptual framework}

Our conceptual framework (Figure 3.1) outlines the various intervention pathways to paddy yields and rice commercialisation levels. It is based on the premise that SRI interventions influence plot and household level outcomes when farmers are both, trained in SRI technologies, and join farmer groups to benefit from continuing technical support and credit facilitation. In our sample, some of the trained farmers opted to adopt SRI using their own resources, and others received training but they did not or could join the SRI farmer groups. Meanwhile, some of the smallholder farmers never attended training, yet they adopted by observing and learning from neighbours and friends (spill-over effects), as illustrated by the dotted line in Figure 3.1.

It is expected, however, that those who attended training are more likely to achieve better yields since they learned the steps first hand. And, even among those who received training, farmers who joined SRI farmer groups are expected to out-perform the non-members since they benefited from regular

Figure 3.1: Conceptual framework on SRI adoption and implication on rice yield

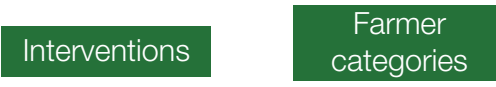

Plot level effect
Household level effects
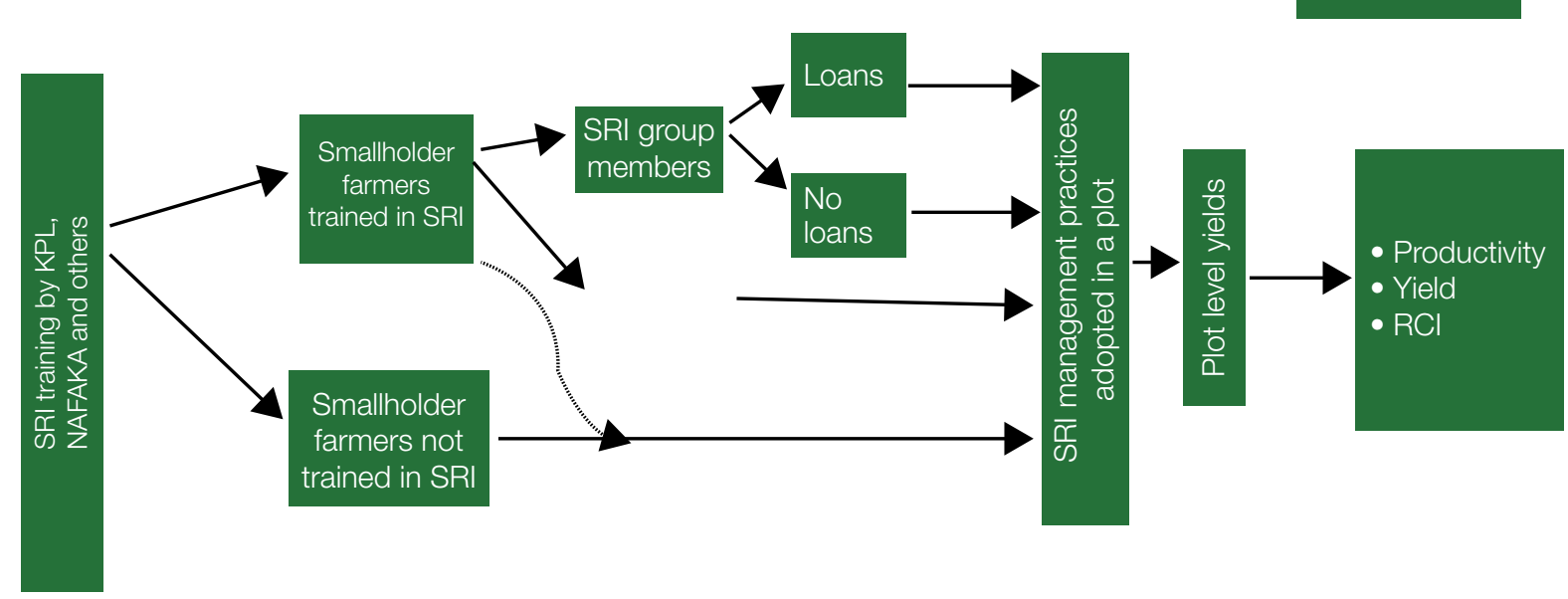

Note: NAFAKA = Tanzania Staples Value Chain

Source: Authors' own 
interactions with other SRI members and followup from KPL facilitators, while some also benefited further through loans. These potential performance differences in terms of yields and production may also translate to higher commercialisation levels. We examined these hypotheses about the adoption and subsequent performance linked with SRI interventions by comparing trained and non-trained farmers, SRI and non-SRI members (of farmer groups). A farmer is considered to have adopted SRI if at least one recommended practice was implemented on at least one paddy plot.

Three hypotheses are examined (stating the null below):

i. There are no significant differences between households with a member trained in SRI and households without a member trained in SRl; and between SRI group and non-SRI group members.

ii. SRI interventions (training, member groups and management practices) had no significant influence on rice yields at the plot level.

iii. SRI interventions had no influence on rice commercialisation.

\subsection{Sampling and data collection}

Quantitative data were collected using a structured questionnaire, which captured a number of variables on SRI technology adoption and related outcomes. These included: household demographics, plot level data on plot characteristics, crops cultivated, input use, agronomic practices, harvest and sales. Specific questions were included on SRI: about SRI training, membership to SRI groups, access to loans, SRI plots and non-SRI rice plots, and SRI management practices. The questions on SRI management practices were about the use of nursery, early and regular weeding and use of fertilisers (leading to three management practices). ${ }^{2}$ Qualitative data were collected using a guided list of open-ended questions, using FGDs in each village and KIls.

\subsection{Empirical strategy}

Descriptive and econometric analyses were conducted using quantitative data post stratification as in Isinika et al. (2020). Preliminary data analysis from the KII information revealed two important points; first, farmers who received SRI training were SRI members and adopters of SRI, but some were also small-scale farmers and medium-scale farmers. Second, there were farmers who were trained on SRI, but did not join SRI groups as mentioned earlier (see Annex 1). Hence, we re-visited the small-scale farmers and SRI classification, similar to Isinika et al. (2020), and reclassified on the basis of SRI training and use of SRI management practices. Using the new grouping, we conducted two analyses: First, plot-level analysis that examined the SRI interventions and corresponding paddy yield; second, we linked this with householdlevel analysis of SRI interventions and the $\mathrm{RCl}$.

\subsubsection{Plot level analysis}

The plot-level analysis consists of three steps:

a. Descriptive analysis of plot attributes and input use to examine if there are clear differences between participants and non-participants of $\mathrm{SRI}$ interventions. An independent sample $\mathrm{t}$ and F-tests is used, and non-parametric test is used to compare medians. A Chi square test is used to examine the association between the SRI interventions and household attributes such as SRI training, sex, age and years of schooling of household head.

b. Analysis of SRI practices and resulting paddy yields, comparing participants and nonparticipants of SRI interventions.

c. Production function analysis of SRI management practices and influence on rice production, controlling for input levels, household and plotlevel characteristics

To understand the likely net effect of SRI intervention for a given plot, it would be necessary to control for observed and unobserved farmer and plot-level attributes that are related to input use and productivity. The differential production function approach in Barrett (2014), using cross-section data, requires a pair of plots (with and without an intervention) from the same farmer. However, while each household in our survey had at least one SRI plot and one non-SRI plot, the validity of such pairing in terms of actual SRI interventions falls apart in our case. Further, Nakano, Tanaka and Keijiro (2017) studied the impact of training on the intensification of rice farming in rain-fed areas in Tanzania using plot-level panel data, employing a Difference in Difference model, allowing for the control of plot-specific and householdspecific time invariant characteristics.

2 However, the questions did not capture further details about the practices such as days to transplanting, actual weed control methods and water use and management. 
Our approach, while inspired by this earlier work, uses a production function model that allows for SRI practices to vary across households (Gathorne-Hardy et al., 2016). The production function is conceptualised as:

$$
Y_{i j}=A_{i j} S_{i j}^{\beta 1} L_{i j}^{\beta 2} F_{i j}^{\beta 3} H_{i j}^{\beta 4} e^{\varepsilon_{i j}}
$$

Where, $Y_{i j}=$ Rice yield for ith farmer on plot $j$ in $t / h a$ $\mathrm{S}_{\mathrm{ij}}=\mathrm{kg} /$ ha of seed used by ith farmer on plot $\mathrm{j}$ $L_{i j}=$ Total labour in days used by ith farmer on plot j

$F_{i j}=$ Total inorganic fertiliser in $\mathrm{kg} /$ ha used by $i^{\text {th }}$ farmer on plot $\mathrm{j}$

$H_{i j}=$ Quantity of herbicide in I/ha used by $i^{\text {th }}$ farmer on plot j

$\varepsilon_{\mathrm{ij}}=$ Disturbance term

$A_{i j}=A$ parameter reflecting the efficiency of transforming the inputs into output (paddy) for $\mathrm{i}^{\text {th }}$ farmer on plot $\mathrm{j}$. The efficiency varies across plots and farmers, reflecting heterogeneity in plot and farmer characteristics.

$\beta_{1}$ to $\beta_{4}$ are partial elasticities of production $\left(0<\beta_{\mathrm{i}}<1\right)$ to be estimated. Logarithmic tranformation of equation 1 yields:

$$
\begin{aligned}
& \ln Y_{i j}=\ln A_{i j}+\beta_{1 j} \ln S_{i j}+\beta_{2 j} \ln L_{i j} \\
& +\beta_{3 j} \ln F_{i j}+\beta_{4} \ln H_{i j}+\varepsilon_{i j}
\end{aligned}
$$

The efficiency of transforming inputs into output is influenced by various factors namely: the biophysical conditions of a given plot (quality of soil), distance from the homestead, management practices applied, and quality of the inputs, among others. We also control for household attributes such as SRI training, sex of household head, age of household and years of schooling of household head. The household-level attributes don't vary across plots, but they interact with plot attributes and SRI practices to influence the efficiency of transforming inputs into outputs.
Therefore, $\ln \mathrm{A}_{\mathrm{ij}}$ can be presented as below:

$$
\begin{aligned}
& \ln A_{i j}=\theta_{o}+\theta_{1} D S Q_{i j}+\theta_{2} H R_{i j}+\rho S R P_{i j} \\
& +\sum_{l} \delta_{l} \text { Plot } * H H_{D} \tau_{i j}
\end{aligned}
$$

Where, DSQ is Soil quality dummy, assigned a value of 1 , if a plot has good soil quality and 0 otherwise, as reported by farmer; HR is plot distance from the homestead to the plot in hours; SRP captures SRI practices denoted as a dummy variable assigned a value of 1 if at least one SRI practice was applied for the plot, and 0 other wise, with the reference category being absence of SRI practices. Plot*HH_D is an interaction term between plot attributes and household attributes where plot attributes distinguish use and non-use of SRI practices (nursery, fertiliser, early and frequency weeding) and household attributes (age, education, household size, land size, livestock onwership, non-farm income and total income). $\tau_{\mathrm{ij}}$ is the disturbance term.

$$
\begin{gathered}
\ln Y_{i}=\theta_{o}+\theta_{1} D S Q_{i j}+\theta_{2} H R_{i j}+\rho S R I P_{i j} \\
+\sum_{l} \delta_{l} \text { Plot } * H_{-} D+\cdots,+\beta_{1} \ln S_{i} \\
+\beta_{2} \ln L_{i}+\beta_{3} \ln F_{i}+\beta_{4} \ln H_{i}+\gamma_{i j}
\end{gathered}
$$

Replacing equation (3) in equation (2), our final equation for the plot-level estimation is presented below: ${ }^{3}$

Where: $\gamma_{i j}=$ is a composite error term equal to $\varepsilon i j+\tau i j$. Annex 2 presents a full description of the variables and the expected signs of the coefficients.

\subsubsection{Household-level analysis: SRI interventions and commercialisation}

Next, we examined the relationship between SRI interventions and rice commercialisation at the household-level using a fractional logit regression model. ${ }^{4}$

We estimate the following:

$$
E(R C I \mid X)=\exp (X \beta) /[1+\exp (X \beta)
$$

3 Interpreting the coefficients from Equation 4: the first part before the inputs is linear (it is based on log-lin funcional form), while the part with inputs is based on log-log functional form. For the log-lin part, the coefficients associated with dummy variables is transformed as exp(coeffient)-1)*100 and reflect a relative change in per cent with respect to the reference group. For coefficients associated with quantitative variables, they are multiplied by 100 and will reflect a relative change in per cent for a unit change of an explanatory variable. Lastly for the inputs, (log-log part) the coeficients reflect a per cent change of mean yield given a 1 per cent change of an input, holding other factors unchanged.

4 The model is preferred to the two limit Tobit corner solution model as it overcomes the possible problem of inconsistent parameter estimates (Wooldridge, 2010). 
Where $\mathrm{RCl}$ represents the commercialisation index defined in the interval (0-1). The vector $X$ includes explanatory and control variables, categorised into household-level attributes (training, farm size, household size, level of education of household head, sex of household head, household total nonfarm income, livestock income and farmer type), and community level or location-level factors (access to extension service and distance to the nearest rice mill). The key variable of interest is SRI training. The parameters are estimated by Bernoulli Quasi Maximum Likelihood Estimation fractional logistic regression (Wooldridge, 2010). 


\section{RESULTS AND DISCUSSION}

\subsection{Household characteristics and SRI interventions}

Table 4.1 presents the comparison of demographic characteristics between participants and nonparticipants of SRI. The SRI participants who received training had a smaller proportion of $\mathrm{FHHs}$, had older household heads $(p<0.1)$, larger families $(p<0.01)$, more land $(p<0.01)$, and higher non-farm and total income. In addition, they were located closer to rice mills on average, and the majority were using mobile money. We found no differences between those with SRI training and those without in terms of years of schooling of household head and land area under paddy production.

SRI training included providing participants with $26 \mathrm{~kg}$ of chemical fertiliser and $4 \mathrm{~kg}$ of SARO-5 rice seeds, likely explaining why so many people went for SRI training in Mngeta division. The training took place over nine years, while our survey was conducted recently in 2016/2017. In addition, KPL facilitated the creation of SRI farmer groups for farmers who had completed training. Instead of continuing to provide free inputs, KPL also facilitated access to loans through Yosefu Microfinance and YETU bank as outlined earlier.

Table 4.2 reports the differences by training, membership to SRI groups and access to loans for adoption of SRI practices. We found that 164 out of 428 sampled small-scale farmers and SRI farmers (38.3 per cent) attended SRI trainings. The adoption rate of SRI technologies was significantly higher among farmers who received training compared to those who did not and this was true both during previous years and during the 2016/17 season.

The fact that non-participants in SRI training also adopted SRI in rice production supports our prior expectation that SRI diffusion to other farmers had been taking place in the villages surrounding KPL. We also observed that SRI adoption had been increasing over time, from about 40 per cent in previous years to 54 per cent in $2016 / 17$. Similarly, this result is comparable with qualitative findings which also

Table 4.1: Household and farm characteristics by SRI training status

\begin{tabular}{|c|c|c|c|c|c|c|c|c|c|c|}
\hline \multirow[b]{2}{*}{ Input } & \multirow[b]{2}{*}{ Units } & \multicolumn{4}{|c|}{ No SRI training } & \multicolumn{4}{|c|}{ SRI training } & \multirow[t]{2}{*}{$\mathrm{p}>|\mathrm{t}| / \chi^{2}$} \\
\hline & & $n$ & Mean & $\begin{array}{l}\text { Std } \\
\text { dev }\end{array}$ & Median & $n$ & Mean & $\begin{array}{l}\text { Std } \\
\text { dev }\end{array}$ & Median & \\
\hline Age of head & years & 264 & 44.6 & 14.9 & 41.0 & 164 & 46.9 & 11.4 & 46.5 & 0.063 \\
\hline Education of head & years & 264 & 5.9 & 2.8 & 7 & 164 & 7.2 & 2.4 & 7 & 0.427 \\
\hline Female-headed & $\%$ & 264 & 16.7 & & & 164 & 9.1 & & & 0.027 \\
\hline $\mathrm{HH}$ size & number & 264 & 4.9 & 2.2 & 5 & 164 & 5.1 & 2.3 & 5 & 0.000 \\
\hline Land size & ha & 264 & 1.9 & 1.2 & 1.6 & 164 & 2.9 & 3.2 & 2.2 & 0.000 \\
\hline Land under paddy & ha & 264 & 1.7 & 2.2 & 1.2 & 164 & 1.8 & 1.9 & 1.4 & 0.140 \\
\hline No. of livestock & TLU & 205 & 1.1 & 2.6 & 0.2 & 141 & 0.9 & 1.4 & 0.3 & 0.340 \\
\hline Non-farm income & $\begin{array}{l}\text { TSh } \\
\text { '000 }\end{array}$ & 264 & 559.2 & 1179.1 & 121.0 & 164 & 1101.6 & 1814.5 & 382.5 & 0.000 \\
\hline Total HH income & $\begin{array}{l}\text { TSh } \\
\text { '000 }\end{array}$ & 264 & 1334.1 & 1884.2 & 767.0 & 164 & 2617.0 & 3390.1 & 1467.9 & 0.000 \\
\hline $\begin{array}{l}\text { Distance to rice } \\
\text { mill }\end{array}$ & $\mathrm{km}$ & 211 & 3.5 & 4.0 & 1.6 & 126 & 2.7 & 3.5 & 1.1 & 0.075 \\
\hline $\begin{array}{l}\text { Mobile money } \\
\text { usage }\end{array}$ & $\%$ of $\mathrm{HH}$ & & 72.2 & & & & 86.6 & & & 0.001 \\
\hline
\end{tabular}

Note: Std dev = standard deviation; $\mathrm{HH}=$ household

Source: Authors' own own using APRA Tanzania data for 2017 
indicated an increase in adoption of SRI practices over time (Isinika and Mwajombe, 2018).

Item 2 in Table 4.2 shows a significant association between SRI adoption and membership to farmers' groups by trained farmers $(p<0.05)$. While about 62 per cent of SRI members adopted SRI practices, only about 47 per cent of non-members trained in SRI adopted the SRI. As shown in Annex 2, the SRI adoption rate in terms of percentage of total rice area under SRI was significantly higher for SRI-trained farmers than nontrained farmers $(p<0.01)$ and for association members compared to non-members $(p<0.1)$.
Access to loans facilitated by KPL was restricted to $S R I$ members only, being availed from 2014/15 to 2016/17. The largest number of beneficiaries were recorded in 2015/16 (Table 4.2). The number of Ioan recipients declined during 2016/17 due to failure to repay loans during previous years. It appears that the loan programme was detested by farmers due to unpopular administrative procedures (Nakano, Tanaka and Keijiro, 2017; Isinika and Mwajombe, 2018). Although a larger percentage of loan recipients adopted SRI than nonrecipients of loans in all three seasons, there was no significant association between adoption of SRI and the receipt of loans in 2014/15 and 2015/16. In 2016/17, 19 out of the 21 loan recipients adopted SRI.

Table 4.2: Household adoption of SRI interventions by SRI training, membership and credit access

\begin{tabular}{|c|c|c|c|c|c|c|c|c|c|}
\hline \multirow{2}{*}{ Period } & \multirow{2}{*}{$\begin{array}{l}\text { Adoption } \\
\text { status }\end{array}$} & \multicolumn{2}{|c|}{ No SRI training } & \multicolumn{2}{|c|}{ With SRI training } & \multicolumn{2}{|c|}{ All } & \multirow[b]{2}{*}{$x^{2}$} & \multirow[b]{2}{*}{$p$} \\
\hline & & $n$ & $\%$ & $n$ & $\%$ & $n$ & Mean & & \\
\hline \multirow[t]{3}{*}{ Previous years } & $\begin{array}{l}\text { Non } \\
\text { adopters }\end{array}$ & 187 & 70.8 & 68 & 41.5 & 255 & 59.6 & 36.23 & 0.000 \\
\hline & Adopters & 77 & 29.2 & 96 & 58.5 & 173 & 40.4 & & \\
\hline & All & 264 & 100 & 164 & 100 & 428 & 100 & & \\
\hline \multirow[t]{3}{*}{ 2016/17 } & $\begin{array}{l}\text { Non } \\
\text { adopters }\end{array}$ & 169 & 64.0 & 63 & 38.4 & 232 & 54.2 & 26.71 & 0.000 \\
\hline & Adopters & 95 & 36.0 & 101 & 61.6 & 196 & 45.8 & & \\
\hline & All & 264 & 100 & 164 & 100 & 428 & 100 & & \\
\hline \multicolumn{10}{|c|}{ Item 2: SRI adoption by trained farmers by membership status } \\
\hline & \multirow{2}{*}{$\begin{array}{l}\text { Adoption } \\
\text { status }\end{array}$} & \multicolumn{2}{|c|}{ Non-members } & \multicolumn{2}{|c|}{ SRI members } & \multicolumn{2}{|c|}{ All } & & \\
\hline & & n & $\%$ & n & $\%$ & $\mathrm{n}$ & $\%$ & $x^{2}$ & p \\
\hline & $\begin{array}{l}\text { Non } \\
\text { adopters }\end{array}$ & 23 & 53.5 & 40 & 33.1 & 63 & 38.4 & 5.60 & 0.018 \\
\hline & Adopters & 20 & 46.5 & 81 & 66.9 & 101 & 61.6 & & \\
\hline & All & 43 & 100 & 121 & 100 & 164 & 100 & & \\
\hline \multicolumn{10}{|c|}{ Item 3: SRI adoption status by loan access of SRI group members } \\
\hline \multirow[t]{2}{*}{ Season } & \multirow{2}{*}{$\begin{array}{l}\text { Adoption } \\
\text { status }\end{array}$} & \multicolumn{2}{|c|}{ No access } & \multicolumn{2}{|c|}{ Had access } & \multicolumn{2}{|c|}{ All } & & \\
\hline & & n & $\%$ & n & $\%$ & $n$ & $\%$ & $\chi^{2}$ & p \\
\hline \multirow[t]{3}{*}{$2014 / 15$} & $\begin{array}{l}\text { Non } \\
\text { adopters }\end{array}$ & 32 & 35.6 & 6 & 24 & 38 & 33.0 & 1.18 & 0.280 \\
\hline & Adopters & 58 & 64.4 & 19 & 76 & 77 & 67.0 & & \\
\hline & All & 90 & 100 & 25 & 100 & 115 & 100 & & \\
\hline \multirow[t]{3}{*}{$2015 / 16$} & $\begin{array}{l}\text { Non } \\
\text { adopters }\end{array}$ & 24 & 40 & 16 & 26.7 & 40 & 33.3 & 2.40 & 0.121 \\
\hline & Adopters & 36 & 60 & 44 & 73.3 & 80 & 66.7 & & \\
\hline & All & 60 & 100 & 60 & 100 & 120 & 100 & & \\
\hline \multirow[t]{3}{*}{ 2016/17 } & $\begin{array}{l}\text { Non } \\
\text { adopters }\end{array}$ & 37 & 34.4 & 2 & 9.5 & 39 & 32.5 & 6.125 & 0.013 \\
\hline & Adopters & 62 & 62.6 & 19 & 90.5 & 81 & 67.5 & & \\
\hline & All & 99 & 100 & 21 & 100 & 120 & 100 & & \\
\hline
\end{tabular}

Source: Authors' own using APRA Tanzania data for 2017 


\subsection{Training and the adoption of SRI management practices}

To examine SRI interventions further, we focused on plots reported as SRI plots by farmers. We examined if the declaration of a plot as SRI was linked with training, and if there were differences between SRI and non-SRI plots in terms of soil quality, distance from homestead, plot size, use of purchased inputs and the resulting paddy yield. Table 4.3 reports a significant association between SRI training status and declared $\mathrm{SRI}$ status $(\mathrm{p}<000)$. This implies that the percentage of farmers who received SRI training reported a greater proportion of SRI plots (80.4 per cent) relative to those without training (62.3 per cent).

Table 4.4 reports the main distinguishing features between SRI and non-SRI plots, consisting of plot area under rice, and frequency of use of inorganic fertiliser and herbicides. We found a significant association between SRI status and use of inorganic fertiliser and herbicides $(p<0.01)$, and significant differences for plot area under rice $(p<0.01)$ and the quantity of herbicide used per hectare $(p<0.05)$. The application of inorganic fertiliser and herbicides was about 13.7 per cent and 12.2 per cent greater on SRI plots than for non-SRI plots, respectively. However, the proportion of plots with fertiliser application was low in general, at about 17.9 per cent for SRI plots and only 4.3 per cent for non-SRI plots. SRI plots were on average larger than non-SRI plots, with a mean difference of $0.3 \mathrm{ha}$, and had a higher average use of herbicides. However, we found no differences in terms of soil quality, distance from the homestead, seeding rate and realised rice yield. The absence of yield differences implies that plot classification based on declared SRI status may not fully reflect how plots were treated and corresponding influence on yield outcomes. Hence, we did a more detailed analysis in terms of implementation of SRI management practices at plot-level. In practice, farmers have a choice of which SRI management practices to use and what modifications to make depending on the

Table 4.3: Distribution of paddy plots by plot type and SRI training status

\begin{tabular}{|l|l|l|l|l|l|l|}
\hline SRI training status & \multicolumn{3}{c|}{ Non-trained } & \multicolumn{3}{c|}{ Trained } \\
\hline
\end{tabular}

Source: Authors' own using APRA Tanzania data for 2017

Table 4.4: Characteristics of paddy plots by declared SRI status

\begin{tabular}{|c|c|c|c|c|c|c|c|}
\hline & (a) & (b) & (c) & (d) & (e) & $(i)$ & \multirow{3}{*}{$\begin{array}{l}(e-b) \\
\text { Mean difference }\end{array}$} \\
\hline & \multicolumn{3}{|c|}{ SRI plots } & \multicolumn{3}{|c|}{ Non-SRl plots } & \\
\hline & $\begin{array}{l}\text { No. of } \\
\text { plots }\end{array}$ & Mean & $\begin{array}{l}\text { Stid. } \\
\text { dev }\end{array}$ & $\begin{array}{l}\text { No. of } \\
\text { plots }\end{array}$ & Mean & Std. & \\
\hline Plot status (\%) & 480 & 69.7 & & 209 & 30.3 & & \\
\hline 'Soil quality’ (\%) & 333 & 69.4 & & 133 & 64.3 & & 5.1 \\
\hline Plot distance (hrs) & 480 & 1.4 & 2.4 & 209 & 1.3 & 1.4 & 0.2 \\
\hline Use of inorganic fertiliser (\%) & 86 & 17.9 & & 9 & 4.3 & & $13.7^{\star \star \star}$ \\
\hline Use of herbicide (\%) & 295 & 61.5 & & 103 & 49.3 & & $12.2^{\star \star \star}$ \\
\hline Plot size (ha) & 480 & 1.2 & 1.6 & 209 & 0.9 & 0.6 & $0.3^{\star \star \star}$ \\
\hline Seed (kg/ha) & 480 & 141 & 824.1 & 209 & 104 & 411.4 & 37 \\
\hline Herbicide (It/ha) & 480 & 2.2 & 2.6 & 209 & 1.8 & 2.4 & $0.4^{\star \star}$ \\
\hline Yield (t/ha) & 480 & 2.6 & 1.6 & 209 & 2.6 & 1.4 & 0.0 \\
\hline
\end{tabular}

Note: Std dev = standard deviation; ${ }^{\star * \star}$ Significant at $p<0.01$, ${ }^{* *}$ significant $p<0.05$, 'Soil quality' in terms of \% is referring to farmers declaring that their soil is of good quality

Source: Authors' own using APRA Tanzania data for 2017 
biophysical conditions of their plots, resources they have and institutional factors.

Table 4.5 reports that about half of the declared SRI plots, 238 (49.6 per cent), had no SRI management practices applied in the years before 2016/17, even though the number of plots with SRI practices increased by 9.2 per cent compared to the previous year. This increase was due to more farmers practicing early and regular weeding alone or in combination with other practices. The common practice of early and regular weeding reflects the prevalent use of herbicides as indicated earlier in Table 4.4 and also observed in the field during 2020 (Isinika, Jeckoniah and Mdoe, 2020). Using a combination of all three practices is not common in Mngeta division and this combination declined by 2.3 per cent in 2016/17.

Since farmer training involved a practical component of implementing the practices on 0.25 acres (0.1ha) of rice field using an offer of $4 \mathrm{~kg}$ of SARO- 5 seed and $26 \mathrm{~kg}$ of inorganic fertiliser (Nakano, Tanaka and Keijiro, 2017), we investigated SRI practice combinations involving early weeding and or fertiliser on SRI plots. Table 4.6 show that 128 (44.5 percent) and 14 9(20.6) of declared $\mathrm{SRI}$ plots belonged to non-trained and non-member of SRI association households respectively had none of SRI practise. These were higher than those of the trained households and members of the SRI association.

Generally, proportions are higher in SRI plots applied only weeding in all categories of household. In addition, Table 4.6 reports that the percentage of SRI plots with two or more SRI practices is higher for households with a member who attended SRI training Percentage plots with SRI practice combinations involving fertiliser and early regular weeding are also higher for SRI-trained farmers than those not trained, and for association members compared to non-members.

Considering all SRI practices involving fertiliser application, SRI-trained famers and association members outperform farmers with no training and

Table 4.5: Distribution of declared SRI plots by number of SRI practices

\begin{tabular}{|c|c|c|c|c|c|}
\hline & \multicolumn{2}{|c|}{ Previous year } & \multicolumn{2}{|c|}{ 2016/17 season } & \multirow[b]{2}{*}{$\%$ change } \\
\hline SRI practices & No. of plots & $\%$ & No. of plots & $\%$ & \\
\hline None $^{\star}$ & 238 & 49.6 & 194 & 40.4 & -9.2 \\
\hline Nursery only & 15 & 3.1 & 11 & 2.3 & -0.8 \\
\hline Early regular weeding & 115 & 24.0 & 146 & 30.4 & 6.4 \\
\hline Fertiliser only & 9 & 1.9 & 12 & 2.5 & 0.6 \\
\hline Nursery and early regular weeding & 20 & 4.2 & 28 & 5.8 & 1.6 \\
\hline Nursery and fertiliser & 3 & 0.6 & 3 & 0.6 & 0.0 \\
\hline Early regular weeding and fertiliser & 34 & 7.1 & 51 & 10.6 & 3.5 \\
\hline All three SRI management practices & 46 & 9.6 & 35 & 7.3 & -2.3 \\
\hline Total & 480 & 100 & 480 & 100 & \\
\hline
\end{tabular}

Note: The total number of plots is 689 of which 480 are SRI plots and 209 are non-SRI plots

Source: Authors' own using APRA Tanzania data for 2017

Table 4.6: Distribution of SRI plots for selected combinations of SRI practices by training status and SRI group membership status

\begin{tabular}{|l|l|l|l|l|l|l|l|l|}
\hline \multirow{2}{*}{} & \multicolumn{3}{|c|}{ Training status } & \multicolumn{3}{c|}{ SRI association membership status } \\
\cline { 2 - 11 } & \multicolumn{2}{|c|}{ Non-trained } & \multicolumn{2}{c|}{ Trained } & \multicolumn{2}{c|}{ Non- member } & \multicolumn{2}{c|}{ Member } \\
\hline Type of SRI practices & $\mathrm{n}$ & $\%$ & $\mathrm{n}$ & $\%$ & $\mathrm{n}$ & $\%$ & $\mathrm{n}$ & $\%$ \\
\hline None SRI practice & 128 & 44.6 & 66 & 14.0 & 14 & 20.6 & 52 & 13.3 \\
\hline Practices with weeding & 108 & 37.6 & 152 & 32.3 & 28 & 41.2 & 124 & 31.8 \\
\hline Weeding and fertiliser & 12 & 4.2 & 74 & 15.7 & 8 & 11.8 & 66 & 16.9 \\
\hline Practices with fertiliser & 18 & 6.3 & 83 & 17.6 & 9 & 13.2 & 74 & 19.0 \\
\hline At least two practices & 21 & 7.3 & 96 & 20.4 & 9 & 13.2 & 74 & 19.0 \\
\hline All & 287 & 100.0 & 471 & 100 & 68 & 100 & 290 & 100 \\
\hline
\end{tabular}

Source: Authors' own using APRA Tanzania data for 2017 
those that are non-members of groups, although the number of plots for the former group is relatively small. These findings suggest that belonging to SRI farmer groups can augment the benefits of training through interaction and regular follow-ups, and may be encouraging members to adopt SRI technologies on more plots. It is likely that networking in farmer groups also broadens people's knowledge and skills so that they see farming as a serious business rather than a routine subsistence activity. Such social interactions also expose farmers to more opportunities that they can learn from and implement in the future (Takahashi and Barett, 2014).

\subsection{SRIl interventions and rice yield}

In this section, we examine if there is any difference in unconditional (without declared SRI status) land productivity between plots with adoption of SRI practices and without SRI practices; between plots belonging to farmers trained on SRI and not trained; and, lastly between SRI members and non-members. Then, we analyse the likely net effects of SRI intervention on paddy yield using a production function.

\subsubsection{SRI practices and rice yields}

We have tried to understand the plausible causes of differences in yields, and if there are clear patterns regarding management practices combining fertiliser application, early and regular weeding. For the entire sample, the mean paddy yield per plot is $2.6 \mathrm{t} / \mathrm{ha}$ with a median of 2.5t/ha (Table 4.7). We observed that relative to plots with either a combination of early and regular weeding and fertiliser or a combination of early regular weeding, fertiliser application and nursery resulted in significantly higher average rice yields $(p<0.01)$, by about 0.9t/ha and 1t/ha respectively (Table 4.7). The mean yield of $4.2 \mathrm{t} /$ ha for plots involving the combination of the three practices is closer to the 4.7t/ha, similar to that reported by Nakano, Tanaka and Keijiro (2017). While all SRI practice combinations show yields above the reported national average of $2 \mathrm{t} / \mathrm{ha}$, these yield levels are however below the average for Morogoro region of $4 \mathrm{t} / \mathrm{ha}$ as reported by the National Bureau of Statistics (NBS, 2018). Generally, this implies that SRI may have had a positive influence on yields, but were lower than what was expected. One likely reason is that farmers were yet to implement all SRI management practices strictly. According to Glover (2011) combinations of SRI management practices have a synergistic effect on yield. Similarly, FGD participants in the study villages reported that higher yield is obtained when farmers applied a combinations of various SRI management practices.

On account of a small number of plots for some SRI practice combinations, and the lack of further details about SRI practices as implemented in the field, a more aggregated analysis was pursued under the assumption that farmers implementing SRI management practices have the knowledge to implement better agronomic rice production practices than farmers without such knowledge. The knowledge was either acquired by participating in training or by field observation or information exchange between farmers. Table 4.8 shows that mean rice yield per plot for farmers who attended training was significantly higher than that of farmers not trained in $S R I(p<0.01)$, with a mean difference of $0.6 \mathrm{t} / \mathrm{ha}$. However, it is important to recognise that this could also reflect a selection bias, especially if more dynamic farmers were more likely to take up the offer of SRI training. Meanwhile, we found

Table 4.7: Plot level rice yield in t/ha by SRI management practices

\begin{tabular}{|c|c|c|c|c|c|}
\hline SRI practices & No. of plots & Mean & Std. dev & Median & Mean diff. \\
\hline No. of SRI practices & 403 & 2.4 & 1.370 & 2.3 & \\
\hline Nursery only & 11 & 2.1 & 1.351 & 1.9 & -0.3 \\
\hline Early regular weeding & 146 & 2.3 & 1.132 & 2.4 & -0.1 \\
\hline Fertiliser only & 12 & 2.3 & 1.391 & 1.9 & -0.1 \\
\hline Nursery and early regular weeding & 28 & 2.7 & 1.424 & 2.7 & 0.3 \\
\hline Nursery and fertiliser & 3 & 2.5 & 0.981 & 3.1 & N/A \\
\hline Early regular weeding and fertiliser & 51 & 3.3 & 1.897 & 3.2 & $0.9^{\star \star \star}$ \\
\hline All three SRI practices & 35 & 4.2 & 2.432 & 3.4 & $1.0^{\star \star \star}$ \\
\hline Total & 689 & 2.6 & 1.505 & 2.5 & \\
\hline
\end{tabular}

Note: a An independent samples t-test was used to compare mean yield between plots with SRI practices and plots without any SRI practices. ${ }^{\star \star \star}=p<0.01$. No SRI practices category includes plots not declared as being SRI; N/A = not applicable due to too small number of observations to make any meaningful comparison.

Source: Authors' own using APRA Tanzania data for 2017 
Table 4.8: Mean differences for paddy yields by training status

\begin{tabular}{|c|c|c|c|c|c|c|c|}
\hline \multirow[b]{3}{*}{ SRI intervention } & (a) & (b) & (c) & (d) & (e) & (i) & \multirow[t]{2}{*}{$(b-e)$} \\
\hline & \multicolumn{3}{|c|}{ Participants } & \multicolumn{3}{|c|}{ Non participants } & \\
\hline & $\begin{array}{l}\text { No. of } \\
\text { plots }\end{array}$ & $\begin{array}{l}\text { Mean } \\
\text { yield (t/ } \\
\text { ha) }\end{array}$ & Std. dev & $\begin{array}{l}\text { No. of } \\
\text { plots }\end{array}$ & $\begin{array}{l}\text { Mean } \\
\text { yield (t } \\
\text { ha) }\end{array}$ & Std. dev & Difference \\
\hline Training & 286 & 2.9 & 1.6575 & 403 & 2.3 & 1.337 & $0.6^{\star \star \star}$ \\
\hline Farmer group Membership & 214 & 2.8 & 1.6431 & 72 & 3.2 & 1.680 & $(-0.4)$ \\
\hline Adopted SRI practices & 286 & 2.8 & 1.6564 & 403 & 2.4 & 1.370 & $0.4^{\star \star \star}$ \\
\hline
\end{tabular}

Std dev = standard deviation; ${ }^{\star \star \star}=$ significant at $\mathrm{p}<0.01$.

Source: Authors' own using APRA Tanzania data for 2017

Table 4.9: SRI interventions and paddy yield: production function analysis

\begin{tabular}{|c|c|c|c|c|c|c|c|}
\hline Variable & Coefficient & $\begin{array}{l}\text { Standard. } \\
\text { error }\end{array}$ & t-statistic & $\mathrm{p}$-value & Confidence & $\begin{array}{l}{[95 \%} \\
\text { Interval] }\end{array}$ & Sig \\
\hline \multicolumn{8}{|l|}{ Household attributes } \\
\hline Sex dummy (1=male) & -0.001 & 0.060 & -0.01 & 0.992 & -0.119 & 0.117 & \\
\hline Age & -0.007 & 0.002 & -3.92 & 0 & -0.010 & -0.003 & 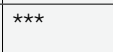 \\
\hline Education & 0.005 & 0.009 & 0.57 & 0.566 & -0.012 & 0.022 & \\
\hline \multicolumn{8}{|l|}{ SRI training } \\
\hline SRI training & 0.126 & 0.033 & 3.76 & 0 & 0.060 & 0.191 & 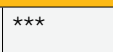 \\
\hline \multicolumn{8}{|l|}{ Production inputs } \\
\hline Ln (seed) & 0.008 & 0.022 & 0.36 & 0.722 & -0.035 & 0.050 & \\
\hline Ln (labour) & 0.111 & 0.020 & 5.51 & 0 & 0.071 & 0.150 & $\star \star \star \star ~$ \\
\hline Ln (fertiliser) & 0.054 & 0.013 & 4.14 & 0 & 0.028 & 0.080 & 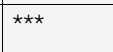 \\
\hline Ln (herbicides) & 0.050 & 0.021 & 2.4 & 0.016 & 0.009 & 0.090 & * \\
\hline \multicolumn{8}{|l|}{ Soil attributes } \\
\hline Soil quality (1=good) & 0.049 & 0.034 & 1.45 & 0.146 & -0.017 & 0.115 & \\
\hline Plot distance (hrs) & -0.002 & 0.004 & -0.47 & 0.642 & -0.011 & 0.007 & \\
\hline \multicolumn{8}{|c|}{ Interaction between household attributes and SRI practices } \\
\hline SRI practices (1=yes) & 0.072 & 0.166 & 0.43 & 0.666 & -0.255 & 0.398 & \\
\hline $\begin{array}{l}\text { SRI practice * sex of } \\
\mathrm{HH} \text { head }\end{array}$ & -0.068 & 0.107 & -0.64 & 0.526 & -0.279 & 0.143 & \\
\hline $\begin{array}{l}\text { SRI practice * SRI } \\
\text { training }\end{array}$ & 0.002 & 0.002 & 0.7 & 0.484 & -0.003 & 0.006 & \\
\hline $\begin{array}{l}\text { SRI practice * age of } \\
\mathrm{HH} \text { head }\end{array}$ & -0.012 & 0.012 & -0.97 & 0.334 & -0.036 & 0.012 & \\
\hline $\begin{array}{l}\text { SRI practice * educ. } \\
\text { Of HH head }\end{array}$ & 0.751 & 0.175 & 4.3 & 0 & 0.408 & 1.095 & 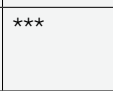 \\
\hline Constant & 0.072 & 0.166 & 0.43 & 0.666 & -0.255 & 0.398 & \\
\hline \multicolumn{2}{|l|}{ Mean dependent var } & 1.177 & \multicolumn{2}{|c|}{ SD dependent var } & \multicolumn{2}{|l|}{0.444} & \\
\hline \multicolumn{2}{|l|}{ R-squared } & 0.164 & \multicolumn{2}{|c|}{ Number of obs } & \multicolumn{2}{|l|}{687.000} & \\
\hline \multicolumn{2}{|l|}{ F-test } & 9.39 & \multicolumn{2}{|l|}{ Prob $>$ F } & \multicolumn{2}{|l|}{0.000} & \\
\hline \multicolumn{2}{|l|}{ Akaike crit. (AIC) } & 740.410 & \multicolumn{2}{|c|}{ Bayesian crit. (BIC) } & \multicolumn{2}{|l|}{808.395} & \\
\hline
\end{tabular}

Note: ${ }^{* \star}$ Significant at $\mathrm{p}<0.01$; ** significant at $\mathrm{p}<0.05$; ${ }^{*}$ significant at $\mathrm{p}<0.1 ; \mathrm{HH}=$ household Source: Authors' own using APRA Tanzania data for $2017 \mathrm{Ln}=$ total cost in.

no significant mean differences in yields at plot level between members and non-members of SRI groups. 
On average, plots with SRI practices had significantly higher rice yields than plots without any SRI practices, with the mean rice yield of SRI plots being higher by $0.4 \mathrm{t} / \mathrm{ha}(\mathrm{p}<0.01)$.

\subsubsection{Production function analysis}

Table 4.9 reports the findings from the production function analysis, controlling for plot level attributes and production inputs. We found a significant association between age of household head and yields, and older household heads with greater use of SRI practices and corresponding yields. Furthermore, SRI training, labour, fertiliser and herbicides are also significantly linked with rice yields. The finding on SRI training is especially important as it suggests that farmer household who attended training attained greater rice yields, which is also consistent with Nakano, Tanaka and Keijiro (2017) and Barrett et al. (2014) who also reported that provision of training to farmers influenced the adoption of SRI practices and subsequent effects on yield.

Further, we found no significant links using interaction terms between household attributes and SRI practices, suggesting that there are likely no moderating influences to build on or impinge the likely gains from $\mathrm{SRI}$ practice. Overall, the production function analysis re-enforces the descriptive analysis regarding the importance of SRI training for rice productivity.

\subsection{SRI interventions and rice commercialisation}

Finally, we examined SRI interventions and the $\mathrm{RCI}$ at household level using fractional logistic regression. Table 4.10 presents the coefficient and marginal effects. We found that SRI training is positively and significantly associated with rice commercialisation, with the mean commercialisation index for trained farmers estimated to be about 9 per cent higher than that of rice farmers without $S R I(p<0.05)$, ceterus paribus. This reflects that training may be linked with improved farmer knowledge on the importance of using SRI practices in enhancing paddy productivity.

Among the control variables, household size has a significant negative coefficient $(p<0.01)$, while total land size, rice yield and access to extension have significant positive coefficients $(p<0.05, p<0.01$ and $p<0.1$ respectively). The marginal effects show that an additional household member is linked with a 3 per cent lower mean commercialisation index; while an additional hectare of land and one metric ton increase in yield is associated with an increase of 4 per cent and 5 per cent in the mean commercialisation index respectively. The mean commercialisation index of farmers with access to extension is about 6 per cent higher than that of farmers without access to extension.

Table 4.10. Determinants of rice commercialisation

\begin{tabular}{|c|c|c|c|c|c|c|}
\hline \multicolumn{7}{|l|}{ Marginal effects } \\
\hline Variable & Coefficient & Robust s.e & $p>z$ & $d y / d x$ & s.e & $p>|t|$ \\
\hline SRI training (1=yes) & $0.3584^{\star \star}$ & 0.1489 & 0.016 & 0.0869 & 0.0363 & 0.016 \\
\hline \multicolumn{7}{|l|}{ Controls } \\
\hline Age of HH head (years) & -0.0072 & 0.0062 & 0.241 & -0.0018 & 0.0015 & 0.241 \\
\hline Education of $\mathrm{HH}$ head (years) & 0.0281 & 0.0337 & 0.405 & 0.0068 & 0.0082 & 0.405 \\
\hline Sex of $\mathrm{HH}$ head (male=1) & 0.1919 & 0.2211 & 0.385 & 0.0465 & 0.0536 & 0.385 \\
\hline $\mathrm{HH}$ size (number) & $-0.1064^{\star \star \star}$ & 0.0388 & 0.006 & -0.0258 & 0.0094 & 0.006 \\
\hline Total land size (ha) & $0.2122^{\star \star}$ & 0.0997 & 0.033 & 0.0514 & 0.0239 & 0.031 \\
\hline Paddy yield (t/ha) & $0.1640^{\star \star \star}$ & 0.0537 & 0.002 & 0.0405 & 0.0131 & 0.002 \\
\hline Access to extension (yes $=1$ ) & $0.2441^{\star}$ & 0.1449 & 0.092 & 0.0592 & 0.0352 & 0.093 \\
\hline Mill distance (km) & -0.026 & 0.0221 & 0.24 & -0.0063 & 0.0054 & 0.240 \\
\hline No. of livestock (TLU) & -0.0554 & 0.0349 & 0.113 & -0.0134 & 0.0085 & 0.113 \\
\hline Constant & -0.1218 & 0.4956 & 0.806 & & & \\
\hline
\end{tabular}

Note: ${ }^{\star \star \star}$ significant at $\mathrm{p}<0.01$; ${ }^{* \star}$ significant at $\mathrm{p}<0.05$; * significant at $\mathrm{p}<0.1 ; \mathrm{HH}=$ household

Source: Authors' own using APRA Tanzania data for 2017 . s.e = standard error; $p=p$ value; $z=z$ value $t=t$ value; $\mathrm{n}=269 \quad$ Wald $\chi 2(11)=47.16 \quad \mathrm{p}>\chi 2=0.0000$ significant at $\mathrm{p}$ greater than $1 \%$. 
Table 4.11 reports a positive and significant link between total land owned by households, level of production and rice commercialisation in Mngeta. The level of commercialisation represented in terms of terciles (Low, Median and High) increases with total land size, yield and rice production. The minimum and maximum cut-off points are as indicated in Annex 3. However, we found no significant relationship between area under

Table 4.11: RCI by farm characteristics

\begin{tabular}{|c|c|c|c|c|c|c|c|}
\hline & $\begin{array}{l}\mathrm{RCl} \\
\text { terciles }\end{array}$ & $\begin{array}{l}\text { No. of } \\
\text { HHs }\end{array}$ & Mean & Std. dev & Median & $F$ & r \\
\hline \multirow[t]{3}{*}{ Total land (ha) } & Low & 146 & 1.8 & 1.3 & 1.4 & 8.4 & 0.00 \\
\hline & Median & 143 & 2.3 & 2.7 & 1.8 & & \\
\hline & High & 144 & 2.8 & 2.5 & 2.3 & & \\
\hline \multirow[t]{3}{*}{ Area under paddy (ha) } & Low & 144 & 1.5 & 1.4 & 1.1 & 1.82 & 0.16 \\
\hline & Median & 141 & 1.7 & 1.6 & 1.2 & & \\
\hline & High & 143 & 2.0 & 3.0 & 1.2 & & \\
\hline \multirow[t]{3}{*}{ Total harvest (t) } & Low & 144 & 3.1 & 3.6 & 2.0 & 4.49 & 0.01 \\
\hline & Median & 141 & 4.5 & 4.9 & 3.0 & & \\
\hline & High & 143 & 4.6 & 5.6 & 3.2 & & \\
\hline \multirow[t]{3}{*}{ Paddy yield (t/ha) } & Low & 144 & 2.2 & 1.2 & 2.2 & 6.04 & 0.003 \\
\hline & Median & 141 & 2.6 & 1.3 & 2.5 & & \\
\hline & High & 143 & 2.7 & 1.5 & 2.6 & & \\
\hline
\end{tabular}

Note: $\mathrm{HH}=$ household; Std dev = standard deviation

Source: Authors' own using APRA Tanzania data for 2017 rice and rice commercialisation. Households with more land, higher production and paddy yield tend to sell a higher proportion of the paddy harvested compared to households with less land, low production and paddy yield ( $p<0.000, p<0.012$ and $p<0.003$ respectively). However, there is no differentiation in the area under paddy across the three levels of commercialisation. 
$\mathrm{SRI}$ is a sustainable agricultural innovation that aims to produce greater yield and reduce costs of production. $\mathrm{KPL}$ introduced this system in Kilombero district in 2009. Globally, SRI technology involved a number of practices promoted as a package, however, in our case study, adoption has varied. This study examined the SRI interventions (based on farmer's selection), paddy yield and rice commercialisation in the Mngeta division in Kilombero district.

To study the links between SRI interventions, yield and commercialisation, the study compared trained and non-trained farmers as well as farmers who were SRI members and non-SRI members. The basis for such comparison being that under the SAGCOT development framework, smallholder farmers were expected to benefit from large-scale farmers within their vicinity through technology transfer or spill-over effects via deliberate efforts on training, farmer groups and credit facilitation.

The findings from this study lead to the following conclusions. First, several practices were promoted by KPL as part of the SRI programme, but adoption was varied as farmers decided to select at least one among the following $\mathrm{SRI}$ practices: raising seedlings in a nursery; planting in rows; early weeding and regular weeding.

There is a significant association between SRI training and adoption of SRI management practices $(p<0.01)$. More than half of the farmers (62 per cent) who received $S R I$ training adopted $S R I$, and 36 per cent of non-trained farmers adopted SRI. We found that plots with SRI practices had a mean yield gain of about 33 per cent above plots without SRI practices. Besides, plots with a combination of SRI practices, either two or more, had more paddy yield.

There is evidence of spill-overs of the SRI training to other farmers who did not attend training. This is a positive message for the sustainability of SRI practices and that, in due course, it is likely that more farmers will adopt and benefit from rice commercialisation. Among the control variables, total land size, rice yield and access to extension have positive and significant link with level of commercialisation. An additional hectare of land and one metric ton increase in yield is associated with an increase of 4 per cent and 5 per cent in the mean commercialisation index respectively.

We found that in order to attain significant yield and commercialisation levels, farmers need to adopt and apply more holistic SRI packages, as selective and varied adoption may limit the gains to be realised. Embracing SRI practices presents an opportunity to increase paddy yields and $\mathrm{RCl}$, and subsequently contribute to improved incomes for farming households. The low application of SRI practices is attributed to the perceived high cost of inputs such as improved seeds and for being labour intensive. Since the experiences from Mngeta division speak to other potential paddy production areas in Tanzania and elsewhere in SSA, we recommend that the Ministry of Agriculture, Food Security and Cooperatives should develop a strategy to enhance understanding of the SRI principles and the importance of adopting a full package of SRI technologies. There is a need for Kilombero District Council to promote adoption of SRI technologies as a package in order to achieve substantial paddy production and income gains. 
Barrettt, C.B. (2014) 'The system of rice intensification and its impacts on household income and child schooling: Evidence from rural Indonesia', American Journal of Agricultural Economics 96 (1): 269-289.

Barrettt, C.B., Moser, C.M., McHugh, O.V. and Barison, J. (2004) 'Better technology, better plots, or better farmers? Identifying changes in productivity and risk among Malagasy rice farmers', American Journal of Agricultural Economics 86: 869-888.

Gathorne-Hardy, A., Reddy, D.N., Venkatanarayana, M. and Hariss-White B. (2016) 'System of Rice Intensification provides environmental and economic gains but at the expense of social sustainability: A multi-disciplinary analysis in India', Agricultural Systems: 143: 159-168.

Glover, D. (2011) 'The System of Rice Intensification: Time for an empirical turn. NJAS -Wageningen Journal of Life Sciences 57: 217-224. Available at: https://doi.org/10.1016/j.njas.2010.11.006 (Accessed: 26 June 2020).

Isinika, A., Mlay, G., Boniface G., Mdoe, N., Poulton, C. and Saha, A. (2020) Does Rice Commercialisation Impact on Livelihoods? Experience from Mgeta in Kilombero District, Tanzania. APRA Working Paper 30. Brighton: Future Agricultures Consortium. Available at: https://www.future-agricultures.org/publications/working-papersdocument/working-paper-30-does-rice-commercialisation-impact-on-livelihood-experience-from-mngeta-inkilombero-districttanzania/ (Accessed: 12 April 2021).

Isinika A., Jeckonia, J. and Mdoe, N. (2020) 'Herbicides: Opportunities and challenges for commercial rice production in Kilombero valley', Future Agricultures Blog, 12 March [online]. Available at: https://www.futureagricultures.org/blog/herbicides-opportunities-and-challenges-for-commercial-rice-production-in-kilomberovalley/ (Accessed: 17 June 2020)

Isinika, A. and Mwajombe, K. (2018) APRA Tanzania WS1 Qualitative Report. Unpublished research report. Brighton: Future Agricultures Consortium.

Kahimba, F.C., Kombe, E.E., and Mahoo, H.F. (2014) 'The Potential of System of Rice Intensification (SRI) to Increase Rice Water Productivity: A Case of Mkindo Irrigation Scheme in Morogoro Region, Tanzania', Tanzania Journal of Agricultural Sciences 12(2): 10-19.

Katambara, Z., Kahimba, F.C., Mahoo, H.F., Mbungu, W.B., Mhenga, F., Reuben, P., Maugo, M. and Nyarubamba, A. (2013) 'Adopting the system of rice intensification (SRI) in Tanzania: A review', Agricultural Sciences 4(8): 369-375.

Krishna, A., Biradarpatil, N.K. and Channappagoudar, B.B. (2008) 'Influence of system of rice intensification (SRI) cultivation on seed yield and quality', Karnataka Journal of Agricultural Science 21(3): 369-372.

Nakano, Y., Tanaka Y. and Keijiro, T.K. (2017) 'Impact of training on the intensification of rice farming: evidence from rain fed areas in Tanzania', Journal of Agricultural System 71: 249-274.

NBS (2018). 2016/17 Annual Agriculture Sample Survey. Crop and Livestock Report. Dar es Salaam: National Bureau of Statistics (NBS). Available at: https://www.nbs.go.tz/index.php/en/census-surveys/agriculturestatistics/57-2016-17-annual-agriculture-sample-survey-crop-and-livestock-final-report (Accessed: 10 June 2020)

Samant, T.K. (2017) 'Promotion of system of rice intensification (SRI) method in mid-central table land zone of Odisha', International Journal of Science, Environment and Technology 6(4): 2276-2282.

Stoop, W.A., Uphoff, N. and Kassam, A. (2002) 'A review of agricultural research issues raised by the System of Rice Intensification (SRI) from Madagascar: Opportunities for improving farming systems for resource-poor farmers', Agricultural Systems 71: 249-274. 
Takahashi, K. and Barrett, C.B. (2014) 'The System of Rice Intensification and its Impacts on Household Income and Child Schooling: Evidence from Rural Indonesia.' American Journal of Agricultural Economics, 96(1): 269-289.

URT. (2009) National Rice Development Strategy Phase I (NRDS I). Dar es Salaam: Ministry of Agriculture, Food Security and Cooperatives. Available at: https://www.jica.go.jp/english/agricultural/pdf/tanzania_en.pdf (Accessed: 10 July 2019).

URT. (2018) Agricultural Sector Reforms in Tanzania: Perspectives from within Ministry of Agriculture. Dar es Salaam: Ministry of Agriculture, Food Security and Cooperatives. Available at: https://www.kilimo.go.tz/index. php/en/resources/view/html/ en.pdf (Accessed: 10 July 2019).

URT. (2019) National Rice Development Strategy Phase II (NRDS II) 2019-2020. Dar es Salaam: Ministry of Agriculture, Food Security and Cooperatives. Available at: https://www.kilimo.go.tz/index.php/en/resources/ view/national-rice-development-strategy-phase-ii (Accessed: 25 May 2020)

Uphoff, N. (2012) 'Comment to the System of Rice Intensification: Time for an empirical turn', NJAS-Wageningen Journal of Life Sciences, 57: 217-224.

West, J. (2017) 'Agricultural investments for development in Tanzania: reconciling actors, strategies and logics?' PhD thesis 2017:35, Norwegian University of Life Sciences, Ås, ISBN 978-82-575-1436-5.

Wilson, C. (2016) Nor fund's Kilombero Plantation in Tanzania - Meagre Results from a Large Investment. Oslo: Farmer group for International Water Studies (FIVAS). Available at: http://fivas.org/wp-content/uploads/2016/03/ fivas1-2016-web.pdf (Accessed: 28 January 2019).

Wooldridge, J.M. (2010) Econometric Analysis of Cross Section and Panel Data. Second Edition. London, UK: MIT Press Books. 
Annex 1: SRI adoption rate in percentage by SRI training and farmer group membership status

\begin{tabular}{|c|c|c|c|c|c|c|}
\hline Variable & N & Mean & Std dev & $\begin{array}{l}\text { Mean } \\
\text { difference }\end{array}$ & S.E & $p$ \\
\hline \multicolumn{7}{|c|}{ Training status } \\
\hline Trained & 164 & 56.5 & 47.5 & $21.9^{\star \star \star}$ & 4.7 & 0.000 \\
\hline Not trained & 264 & 34.6 & 46.9 & & & \\
\hline All & 428 & 43.1 & 48.3 & & & \\
\hline \multicolumn{7}{|c|}{ SRI association membership } \\
\hline Member & 121 & 60.5 & 46.2 & $15.1^{*}$ & 8.7 & 0.070 \\
\hline Not member & 43 & 45.3 & 49.8 & & & \\
\hline All & 164 & 56.5 & 47.5 & & & \\
\hline
\end{tabular}

Note: ${ }^{* * \star}$ significant at $\mathrm{p}<0.01$; ${ }^{*}$ significant at $\mathrm{p}<0.1 ;$ Std dev $=$ standard deviation; S.E. $=$ standard error Source: Authors' own

Annex 2: Description of production inputs and plot level variables for the production function

\begin{tabular}{|c|c|c|c|}
\hline $\begin{array}{l}\text { Variable } \\
\text { name in } \\
\text { methodology }\end{array}$ & $\begin{array}{l}\text { Variable name in } \\
\text { results }\end{array}$ & Description & $\begin{array}{l}\text { Expected } \\
\text { sign }\end{array}$ \\
\hline \multicolumn{4}{|l|}{ Production inputs } \\
\hline InS & Ln (seed) & Log of quantity of seed in $\mathrm{kg} / \mathrm{ha}$ & $-^{+}$ \\
\hline $\operatorname{lnL}$ & Ln (labour) & Log of labour in man-days/ha & + \\
\hline $\ln F$ & Ln (inorganic fertiliser) & Log of quantity of fertiliser in $\mathrm{kg} / \mathrm{ha}$ & + \\
\hline $\mathrm{InH}$ & Ln(herbicide) & Log of amount of herbicide applied in It/ha & + \\
\hline \multicolumn{4}{|c|}{ Plot attribute variables } \\
\hline $\mathrm{DSQ}$ & Soil dummy (1=good) & $\begin{array}{l}\text { A dummy variable assigned a value of } 1 \text { if the soils is of good } \\
\text { quality and } 0 \text { if the soil is fair or poor }\end{array}$ & + \\
\hline $\mathrm{HR}$ & Plot distance & Distance of a plot from the homestead in hours & - \\
\hline SRIP & SRI practice & $\begin{array}{l}\text { A dummy variable assigned a value of } 1 \text { if SRI practices were } \\
\text { used and } 0 \text { if none was used }\end{array}$ & + \\
\hline \multicolumn{4}{|c|}{ Interaction between plot and household attributes } \\
\hline $\begin{array}{l}\text { SRI_pract*sex } \\
\text { of hh }\end{array}$ & PLOT*HH_D & $\begin{array}{l}\text { Interaction between SRI practices dummy variable and sex of } \\
\mathrm{HH} \text { dummy (sex=1 if head) }\end{array}$ & $--/+$ \\
\hline $\begin{array}{l}\text { SRI_pract*age } \\
\text { of hh }\end{array}$ & PLOT*HH_D & $\begin{array}{l}\text { Interaction between SRI practices dummy variable and age of } \\
\mathrm{HH} \text { head }\end{array}$ & - \\
\hline $\begin{array}{l}\text { SRI_pract_Educ } \\
\text { of hh }\end{array}$ & PLOT*HH_D & $\begin{array}{l}\text { Interaction between SRI practices dummy variable and years of } \\
\text { schooling of } \mathrm{HH} \text { head }\end{array}$ & + \\
\hline $\begin{array}{l}\text { SRI_pract*SRI_ } \\
\text { train }\end{array}$ & PLOT*HH_D & $\begin{array}{l}\text { Interaction between SRI practices dummy variable and SRI } \\
\text { training dummy variable }\end{array}$ & + \\
\hline
\end{tabular}

Note: $\mathrm{HH}=$ household

Source: Authors' own 
Annex 3: Terciles of rice commercialisation

\begin{tabular}{|l|l|l|l|l|l|}
\hline Terciles & N & Mean & Median & Minimum & Maximum \\
\hline Low tercile & 144 & 25.1177 & 29.7050 & .00 & 50.00 \\
\hline Median tercile & 141 & 63.6875 & 64.2900 & 50.75 & 75.37 \\
\hline High tercile & 143 & 86.0536 & 83.3300 & 75.46 & 100.00 \\
\hline Total & 428 & 58.1835 & 64.2900 & .00 & 100.00 \\
\hline
\end{tabular}

Note: $F=834$ P-value 0.000

Source: Authors' own 
Mosha, D.B., Mlay, G., Poulton, C., and Saha, A. (2021) Yield and Commercialisation Effects of SRI Interventions in Mngeta, Kilombero District, Tanzania, APRA Working Paper 66, Brighton: Future Agricultures Consortium

(c) APRA 2021

ISBN: 978-1-78118-849-1

DOI: 10.19088/APRA.2021.025

\section{(cC) BY-NC-ND}

This is an Open Access report distributed under the terms of the Attribution-Non Commercial-No Derivs 4.0 Unported (CC BY-NC-ND 4.0) Attribution - You must give appropriate credit, provide a link to the license, and indicate if changes were made. You may do so in any reasonable manner, but not in any way that suggests the licensor endorses you or your use. NonCommercial — You may not use the material for commercial purposes. NoDerivatives - If you remix, transform, or build upon the material, you may not distribute the modified material. You are free to: Share - copy and redistribute the material in any medium or format.

https://creativecommons.org/licenses/by-nc-nd/4.0/legalcode

If you use the work, we ask that you reference the APRA website (www.future-agricultures.org/apra/) and send a copy of the work or a link to its use online to the following address for our archive: APRA, Future Agricultures Consortium, University of Sussex, Brighton BN1 9RE, UK (apra@ids.ac.uk)

All APRA Working Papers go through a review process before publication.

\section{@creative}

\section{DO YOU HAVE COMMENTS ON THIS PAPER?}

We would welcome your feedback on this working paper!

To provide brief comments, please follow this link to our short APRA Working Paper Feedback form: https://goo.gl/forms/1iVnXhhrIGesfR9

Agricultural Policy Research in Africa (APRA) is a programme of the Future Agricultures Consortium (FAC) which is

generating new evidence and policy-relevant insights on more inclusive pathways to agricultural commercialisation in sub-Saharan Africa. APRA is funded with UK aid from the UK Foreign, Commonwealth \&

Development Office (FCDO) and will run from 2016-2022.

The APRA Directorate is based at the Institute of Development Studies (IDS), UK (www.ids.ac.uk), with regional hubs at the Centre for African Bio-Entrepreneurship (CABE), Kenya, the Institute for Poverty, Land and Agrarian Studies (PLAAS), South Africa, and the University of Ghana, Legon. It builds on more than a decade of research and policy engagement work by the Future Agricultures Consortium (www.future-agricultures.org) and involves more than 100 researchers and communications professionals in Africa, UK, Sweden and USA. 